\title{
Connecting Research and Teaching Through The Creation of a Staff Research Lab: A Case History.
}

\author{
Gaëlle Villejoubert (g.villejoubert@kingston.ac.uk) \\ Department of Psychology, Faculty of Arts and Social Sciences, Penrhyn road \\ Kingston upon Thames, KT1 2EE UK
}

Reprint. Please cite as Villejoubert, G. (2012). Connecting research and teaching through the creation of a staff research lab: a case history. in T. Lindsey and A. Law (Eds.) Quality Enhancement in Learning and Teaching: How Kingston University is improving the Student Experience (pp. 57-59). Kingston-upon-Thames: Academic Development Centre.

For over two centuries, universities have been portrayed as centres of 'higher learning' where advanced scientific and scholarly research were to be embedded in higher education (Collini, 2012; Simons \& Elen, 2007). More recently, the Lisbon agenda and the Bologna process highlighted the need to tighten the relationship between student learning of an academic discipline and research within this discipline as a key strategic priority to enable modern universities to set themselves apart from other institutes of higher education. (Elsen, Visser-Wijnveen, van der Rijst, \& van Driel, 2009).

Yet, implementing a tight "teaching-research nexus" (Neumann, 1994) in practice bears more semblance to a grail quest than to an achievable goal. Academics are under pressure to operate with ever-decreasing staff-student ratios but also to excel at teaching, meet students' needs, and provide them with a business-engaged education. These radical transformations of the higher education landscape in the past two decades left many modern academics struggling to find the time to sustain their research and scholarly activities, not to mention involving students in such activities. So, while a strong teachingresearch connection remains an ideal shared by many, it is unclear how this vision can be realised within the current context.

In this article, I share my experience and my attempt to meet this challenge through the creation of a "staff research lab," to engage my students with my research activities. I do this by presenting a short case history recounting the creation of the lab, its impact on students' experience and my own.

I set up "my lab" in 2009 when I joined the Department of Psychology at Kingston. Because of their history and their association with the "hard sciences," research labs are often seen as necessitating a hefty initial investment, but this needs not be so. My lab merely started with an acronym: GRULaK ("Gaelle's Risk and Uncertainty Lab at Kingston") and a Facebook page where I posted recent articles related to my area of expertise - the psychology of risk and decision-making. I then invited my final year tutees to join the group. Most of them did and some even immediately engaged with the papers, commenting on my posts. At the beginning of the 2010 academic year, I met with all my supervisees together and told them that, since they were to work with me, they earned the much soughtafter title of GRULaKee! We were to hold a weekly GRULaK meeting to talk about research in general, and their progress on their own research work in particular, while sharing some nibbles and cake. Within a few weeks, we were no longer conversing, we had become a team. They got to know and engage with each other's respective projects, rapidly turning into buddying academics. I would arrive at our weekly meeting to find them already there, discussing papers, sharing references... and nibbles. One of the students in the group recalls: "I loved our GRULAK meetings! We would bring snacks to share while presenting our undergraduate research ideas to each other and share thoughts on methods or discuss how to solve the problems we were facing at the time. We recruited participants together, discussed how to interpret results over coffee and proof-read each other's written reports. We started as students who worked in a related area of psychology, we ended up as colleagues and friends."

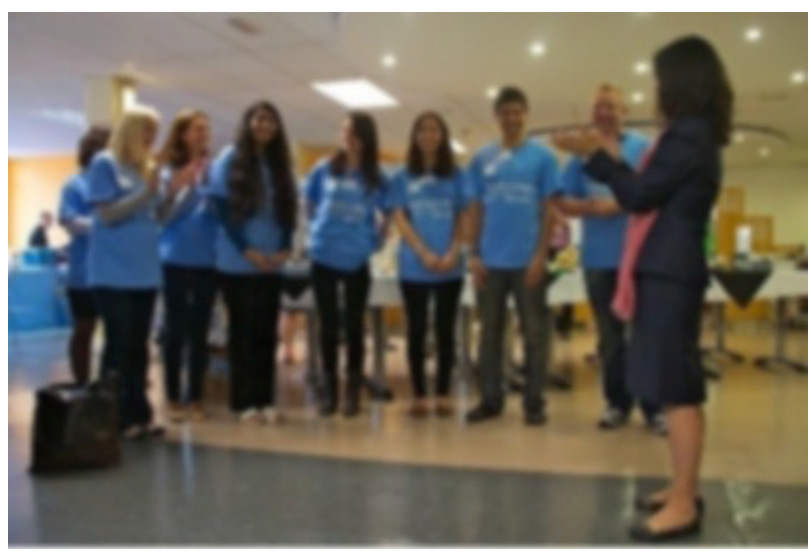

Figure 1: GRULaKees get a standing ovation for their superb work at SPUDM23! — Original photo by David

K. Hardman

Our exchanges often went beyond their work. They started to ask me about my own research. I told them about the large conference I was organising that year. They had no idea about what a conference was, but they were intrigued. By the end of the year, almost all GRULaKees had applied to be a student helper at the conference. Another member of the lab mentioned that it was during that conference, where he met $\mathrm{PhD}$ students and more senior researchers whose work, he had read during his undergraduate research project, that he started to make plans to pursue a $\mathrm{PhD}$ in decision-making in the near future. Another student added: "Being able to meet and talk to conference delegates was a great confidence booster and a wonderful learning 
experience. The highlight of the event was definitely the moment when our group stood with Prof. Daniel Kahneman-a Nobel Prize winner! - in the middle of the Foodstore, and all the delegates applauded us for our work at the conference!"

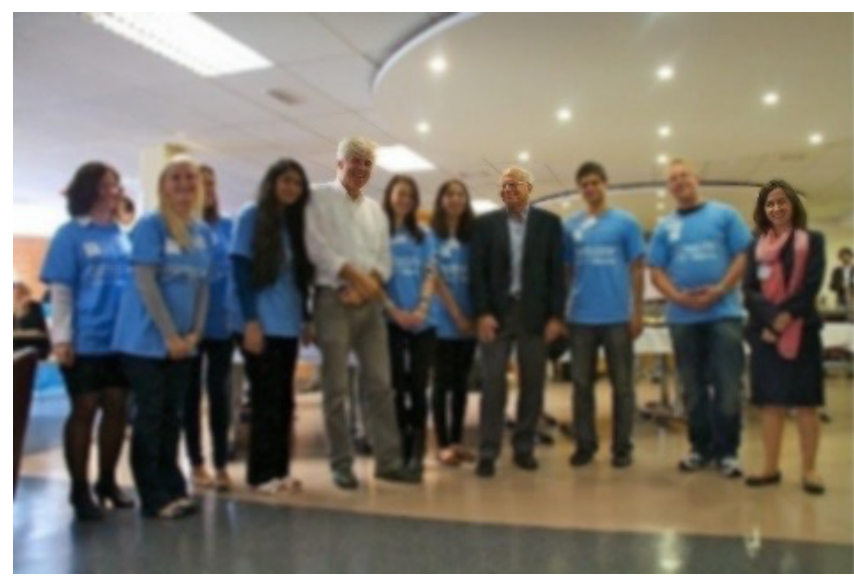

Figure 2: GRULaKees meet SPUDM23 plenary speakers: Prof Danny Kahneman and Prof Peter Ayton - Original photo by David K. Hardman

Today, GRULaK has evolved into a fully blown website, a small community of four $\mathrm{PhD}$ students, postgraduates and undergraduates who work on different projects, some for their course, some as volunteer research assistants. The activities of the lab continue to be informed by my own research interests but are also inspired by students' initiatives. Lab alumni have kept in touch and come back to visit.

All in all, GRULaK transformed my academic relationship with my students. At times when we are asked what universities are for in general, and modern universities in particular; when we are requested to mind our students' levels of satisfaction or demonstrate that their learning is useful; when 'time' for research seems more and more elusive, I found my research lab has become a precious nook where I can finally bring research and learning together with a human touch, and properly share what it means to be an academic with my students, challenge their ideas and get them to challenge mine, transform their view of their discipline and get to show them what research really is about. I thoroughly recommend it: think about it, all you need is an acronym, an open invitation, a paper for discussion... and a few nibbles to start with.

\section{References}

Jensen, J. (1988). Research and teaching in the universities of Denmark - does such an interplay really exist. Higher Education, 17, 17-26.

Neumann, R. (1994). The teaching-research nexus: applying a framework to university students' learning experiences. European Journal of Education, 29, 323-339. Simons, M., \& Elen, J. (2007). The 'research-teaching nexus' and 'education through research': An exploration of ambivalences. Studies in Higher Education, 32, 617- 631.
Collini, S. (2012). What are universities for? London: Penguin.

Elsen, M., Visser-Wijnveen, G. J., van der Rijst, R. M., \& van Driel, J. H. (2009). How to strengthen the connection between research and teaching in undergraduate university education. Higher Education Quarterly, 63, 64-85. doi: 10.1111/j.1468-2273.2008.00411.x 